\title{
DERMATITE DE CONTACTO ALÉRGICA A SOMBRA DE OLHOS
}

\author{
Catarina Araúio', Cristina Resende', Teresa Pereira², Celeste Brito ${ }^{3}$ \\ IInterna do Internato Complementar de Dermatologia e Venereologia/Resident, Dermatology and Venereology \\ ${ }^{2}$ Assistente Hospitalar de Dermatologia e Venereologia/Consultant, Dermatology and Venereology \\ ${ }^{3}$ Chefe de Serviço, Directora do Serviço de Dermatologia e Venereologia/Consultant Chief, Head of Department of \\ Dermatology and Venereology \\ Serviço de Dermatologia e Venereologia, Hospital de Braga, Sete Fontes - São Victor, Braga, Portugal
}

RESUMO - Introdução: A dermatite de pálpebras secundária à exposição a cosméticos é descrita na literatura entre $2.5 \%$ e $26 \%$. A maquilhagem pigmentada pode conter alergénios metálicos, incluindo níquel, crómio e cobalto. Caso clínico: Doente do sexo feminino, 52 anos, cabeleireira, com antecedentes de atopia. Recorreu à consulta de Dermatologia com história de prurido, eritema e descamação das pálpebras com 7 meses de evolução. Na sua história médica passada foi referida dermatite do lóbulo da orelha aos brincos. Foi encaminhada à consulta de Alergologia Cutânea para realização de testes epicutâneos com a série básica do Grupo Português de Dermatite de Contactos, série cosméticos, série cabeleireiro e os produtos pessoais da doente (em teste semiaberto). Foram observadas reacções positivas ao sulfato de níquel $5 \%$ em vaselina (++ em D3) e valentina D kejal ${ }^{\circledR}$ (sombra de olhos cinzenta). Conclusões: Os cosméticos são uma potencial fonte sensibilizante da pele da face, especialmente em mulheres com atopia e alteração da barreira cutânea, o que favorece a penetração de alergénios. Isto permite que o níquel em baixas concentrações, mesmo que, como contaminante, desencadeie reacção palpebral.

PALAVRAS-CHAVE - Dermite: de contacto alérgica; Pálpebras; Sombra de olhos; Maquilhagem; Níquel.

\section{ALLERGIC CONTACT DERMATITIS TO AN EYELID SHADOW}

ABSTRACT - Introduction: The published percentage of patients with eyelid dermatitis from cosmetic exposure lies between 2.5\% and 26\%. Pigmented make-up may contain metal allergens, including nickel, chromium and cobalt. Case report: A 52-year-old atopic woman, hairdresser, with a 7-month history of itching, erythema and scaling of both eyelids. Her medical history revealed earlobe dermatitis in childhood. She was referred for patch-testing in our contact allergy department with baseline series from Portuguese Contact Dermatitis group (GPEDC), cosmetic and hairdresser series and the patient's own products in semi-open test. Positive reactions were observed to nickel sulphate $5 \%$ in petrolatum ( + at D3) and valentina D kejal ${ }^{\circledR}$, grey eye shadow (++ at D3). Conclusions: Cosmetics are a potentially sensitizing source, on thin facial skin and especially for atopic woman, who have a damaged skin barrier that may favour penetration of allergens, allowing lower nickel concentrations, even as a contaminant, to trigger an eyelid reaction.

KEY WORDS - Allergic contact dermatitis; Eyelid; Shadow; Make-up; Nickel.

\footnotetext{
Conflitos de interesse: Os autores declaram não possuir conflitos de interesse.

No conflicts of interest.

Suporte financeiro: $O$ presente trabalho não foi suportado por nenhum subsídio ou bolsa.

No sponsorship or scholarship granted.

Direito à privacidade e consentimento escrito / Privacy policy and informed consent: Os autores declaram que pediram consentimento ao doente para usar as imagens no artigo. The authors declare that the patient gave written informed consent for the use of its photos in this article.
}

Recebido/Received - Dezembro/December 2014; Aceite/Accepted - Janeiro/January 2015 
Correspondência:

Dr. ․ Catarina Araújo

Serviço de Dermatologia e Venereologia

Hospital de Braga, Sete Fontes - São Victor

4710-243 Braga, Portugal.

Tel.: + 351-253-027-000

Fax: +351-253-027-999

E-mail: catarina.portela.aravjo@gmail.com

\section{INTRODUTION}

The eyelid is one of the most sensitive areas of the body as the skin of the eyelid is extremely thin compared to facial skin and it is exposed to an extraordinary number of substances. Allergic contact dermatitis (ACD) of the eyelids is often an ectopic manifestation caused by cosmetics applied to the hair, face, scalp or fingernails and it is also particularly susceptible to $A C D$ from airborne substances. Blepharitis can also result from direct application of cosmetics.

The published percentage of patients with eyelid dermatitis from cosmetic exposure lies between the extremes of $2.5 \%$ and $26 \%^{2}$ with fragrances and preservatives being the most common culprit sensitizing substances along with weak irritants. Pigmented make-up may contain metal allergens, including nickel, chromium and cobalt. They are potentially sensitizing sources, on thin facial skin and, especially for atopic woman, who have a damaged skin barrier that may favour penetration of allergens.

\section{CASE REPORT}

A 52-year-old atopic woman, hairdresser, with a 7-month history of itching, erythema and scaling of both eyelids (Fig. 1). Her medical history revealed earlobe dermatitis in childhood. She was referred for allergological study and patch-testing in our contact allergy department with baseline series from Portuguese Contact Dermatitis group (GPEDC), cosmetic and hairdresser series and the patient's own products in semi-open test. Allergens were applied to the upper back for $48 \mathrm{~h}$ using Finn Chambers in accordance with accepted concentrations and vehicles. The results were read at third and seventh day after placement of the patches. Positive reactions were observed to nickel sulphate $5 \%$ in petrolatum $(++$ at D3) and valentina D kejal ${ }^{\circledR}$, grey eye shadow (++ at D3). The remaining tested allergens were negative (Fig. 2). The

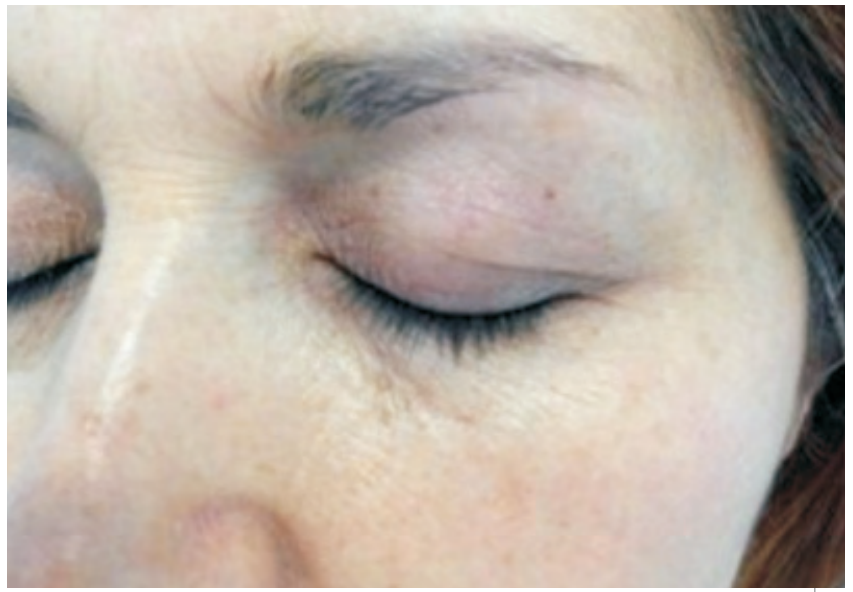

Fig 1 - Clinical picture after 7-month history of itching, erythema and scaling of both eyelids.

dermatitis improved when the patient stopped using the eye shadow.

\section{DISCUSSION}

Cosmetics represent an important source of sensitization, since they are used every day, mainly in woman. An association between nickel eyelid dermatitis and nickel in make-up products remains controversial.

Nickel is a chemical element found ubiquitously in the environment in numerous industrial and consumer products and is used with a high frequency worldwide. It is electrophilic, and so it has the ability to ionize and react with proteins, thus forming complexes that can be recognized by dendritic cells, which allows for sensitization to occur. Nickel allergy affects women 3 to 10 times more than men and is usually due to daily contact with jewellery and garments from non-occupational exposure. However, the number of women with relevant occupational exposure is increasing ${ }^{3}$.

Although no measurement of nickel in shadow eyelid had been performed, by atomic absorption spectroscopy ${ }^{4}$, the amount of nickel, in this patient, was 


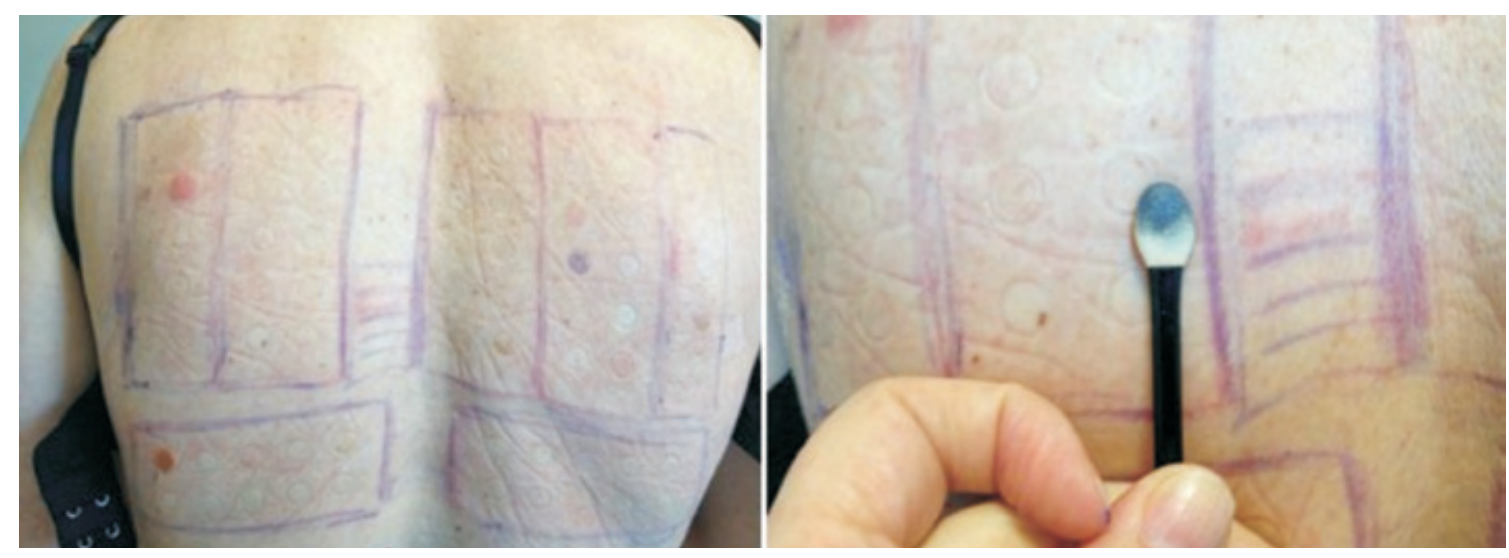

Fig 2 - Positive reactions were observed to nickel and valentina D kejal ${ }^{\circledR}$, grey eye shadow, at day 3.

shown to be important. Metallic nickel and some of its salts are prohibited by the European Commission ${ }^{5}$ in cosmetic products, but their presence is permitted in very low quantities, defined as "impurities". Although it was not possible to obtain information from the producer, nickel was probably present as a contaminant.

Eyebrow pencil 6 , mascara ${ }^{7}$, eye shadow ${ }^{8}$, foundation products ${ }^{9}$, toy make-up ${ }^{4}$ and instruments, such as an eyelash curler ${ }^{10}$ and powders are the most commonly reported cases with allergic contact dermatitis caused by nickel in make-up products.

It is described that powdery make-up (eye shadow) had the highest levels of metals and creamy make-up (lip gloss and lipsticks) the lowest ${ }^{4}$. By the other hand, a recent cross-sectional general population study, found no association between having nickel allergy and cosmetic dermatitis caused by mascara or eye shadow. Allergen sources of clinical relevance in eye shadow were fragrance mix l, myroxylon pereirae and thimerosal ${ }^{11}$. In other study designed to investigate whether nickel sensitized individuals react to make-up products containing pigments with nickel as an impurity, none of the nickel-sensitive individuals reacted to the test products ${ }^{12}$. However, in this study ${ }^{11}$, patients were exposed to mineral make-up and this fact may take in account for a lower level of nickel impurities in modern make-up.

Interestingly our patient developed allergic contact dermatitis present in shadow eyelid demonstrating the importance of the cosmetics when eyelid dermatitis is assessed and that nickel may be present in other sources of exposure of metallic objects. Our case did not assess bio-available nickel concentrations, the clinical relevance of nickel concentration in eye shadows could not be determined with certainly. However, the thin stratun corneum on the eyelids, exposure to sweat (resulting in occlusion and release free nickel ions that act as haptens) and an atopic damaged skin barrier (that may favour nickel skin absorption), allow lower nickel concentrations, same as a contaminant, to trigger a eyelid reaction.

\section{CONCLUSIONS}

Cosmetics are a potentially sensitizing source, on thin facial skin and especially for atopic woman, who have a damaged skin barrier that may favor penetration of allergens, allowing lower nickel concentrations, same as a contaminant, to trigger an eyelid reaction.

\section{REFERÊNCIAS}

1. Borrie P. Eczema of the eyelids. Br J Ophthalmol 1956; 40:742-50.

2. Kaalund-Jorgensen O. Eczema perioculare (dermatitis of the eyelids) Acta Derm Venereol 1951; 31:83-90.

3. Andersen KE, White IR, Goossens A. Allergens from the standard series. In: Frosch PJ, Menné T, Lepoittevin JP, editors. Contact dermatitis, $4^{\text {th }}$ ed. New York. Springer; 2006. p. 455.

4. Corazza M, Baldo F, Pagnoni A et al. Measurement of nickel, cobalt and chromium in toy make-up by atomic absorption spectroscopy. Acta Derm Venereol. 2009; 89(2):130-3.

5. European Commission Regulation no. 1223/2009 of the European Parliament and of the Council of 30 November 2009 on cosmetic products: annex II: 1093. 
6. Travassos AR, Bruze M, Dahlin J et al. Allergic contact dermatitis caused by nickel in a green eye pencil. Contact Dermatitis 201 1: 65:302-9.

7. Karlberg AT, Liden C, Ehrin E. Colophony in mascara as a cause of eyelid dermatitis. Chemical analyses and patch testing. Acta Derm Venereol 1991: 71:445-7.

8. Goh CL, Ng SK, Kwok SF. Allergic contact dermatitis from nickel in eyeshadow. Contact Dermatitis 1989; 20:380-1.

9. Foulds I S. Facial eczema due to colour pigments in foundationmakeup in nickel-sensitive patients.
Contact Dermatitis 2006: 55 (Suppl. 1):11.

10. Henke U, Boehncke W. Eyelid dermatitis caused by an eyelash former. Contact Dermatitis 2005:5327.

11. Thyssen JP, Linneberg A, Menne T et al. No association between nickel allergy and reporting cosmetic dermatitis from mascara or eye shadow: a cross-sectional general population study. J Eur Acad DermatolVenereol 2010: 24:722-5.

12. Loden $M$, Nilsson $G$, Parvardeh $M$ et al. No skin reactions to mineral powders in nickel-sensitive subjects. Contact Dermatitis 2012; 66:210-4. 